\title{
Water-Demand Management in the Kingdom of Saudi Arabia for Enhancement Environment
}

\author{
Magdy Shayboub Ali Mahmoud ${ }^{1,2^{*}}$, Samir Mahmoud Adam Abdallh ${ }^{2}$ \\ ${ }^{I}$ Computer Science Dept., Faculty of Computers and Informatics, Ismaillia 41522, Suez Canal University, \\ Egypt \\ ${ }^{2}$ Computer Science Dept., , Applied Medical Sciences College Of Taif University, Kingdom of Saudi Arabia \\ (KSA) \\ ${ }^{2}$ Computer Science Dept., Applied Medical Sciences College Of Taif University, Kingdom of Saudi Arabia
} (KSA)

\begin{abstract}
The purpose and the goal of the paper is growing substantially demand for water and waste-water infrastructure and that is being met through the available scarce and dwindling water resources. The kingdom of Saudi Arabia (KSA) faces an acute water shortage due to arid climate and absence of permanent lakes and rivers. Ever-increasing imbalances are usually met by increasing water supplies, whereas the concepts of water-demand management have not been given due importance and weight age. Meeting the rapidly rising demand with scarce and depleting resources remains the critical issue. This paper places emphasizes on the urgency of adopting conservation and water-demand management initiatives to maintain demand supply relationship and achieve an acceptable balance between water needs and availability. Demand for water and waste-water infrastructure projects has remained unaffected by the global financial crisis, and it continue to grow exponentially. Waste-water is a rapidly and globally expanding area of infrastructure development, that enables the sustainable re-use of scarce water resources for non-potable purposes in industry, agriculture, and greening. particularly in the agricultural sector-the largest and most inefficient user of water have been suggested. The paper suggests that the water-use-efficiency (WUE) in various sectors can be enhanced and improved in a local area of the kingdom of Saudi Arabia. The objective of this paper is to safeguard and conserve this precious natural resource through environmental enhancement technologies for the future generations to come. It is presumed that water resources can be managed on sustainable basis by devising and employing environmental technologies including water conservation measures and develop water for sustainability and efficiency. The main goal of this paper is showing; how Geographical Information Systems (GIS) can be used to support infrastructure of demand water and waste-water. To improve governance and management to the highest level. Provide water service to the Saudi people up to the level of developed countries whilst minimizing the fiscal burden. To develop and introduce technological and institutional innovations. To conserve and enhancement the environment. The usefulness of these measures can be supplemented through the vibrant and viable extension and education initiatives and capacity building programs. In this work, three sets applications of GIS models have been produced. The geodatabase of district areas in Saudi Arabia including these layers of area, Subarea, cites, water in land, water area, land cover, roads, railroads, elevations and mountains.
\end{abstract}

Keywords: Water Demand, Water Resources, GIS, Highway Street, XML Schema.

\section{Introduction}

The kingdom of Saudi Arabia (KSA) places emphasis on the shift from supply development to demand management to use of critical and non-renewable water resources efficiently. The paper presents an overview of the country's water resources and issues related to water. Some possible conservation and remedial measures. Few countries face water shortages as extreme as Saudi Arabia. Its water scarcity poses a significant risk to the feasibility and profitability of many energy projects. We may see investors targeting projects where water is less important - such as solar PV, wind and natural gas - and avoiding those that involve high water usage, such as biofuels. Another issue is the role of energy in the extraction, treatment and transportation of water. By some estimates, about half of Saudi Arabia's domestic oil consumption is used to desalinate water. Attracting investment in independent water projects will require a focus on increasing the rate of return for investors and reducing their exposure to risk.

Saudi Arabia with an area of 2.15 million $\mathrm{km}^{2}$ is an arid and water deficit country, with limited fresh water-supplies in subarea. The kingdom of Saudi Arabia (KSA) is a desert like country lying within the continental zone in Saudi Arabia area and subareas as shown in figures 1 and 2, where temperatures are high in summer and low in winter for all cities except south area. It is also characterized by low annual rainfall and lacks perennial rivers or permanent bodies of water. The climatic conditions pose a continual challenge, as does the depletion of underground water resources in KSA. Due to an acute deficit, water has always been an extremely valuable resource and occupies the prominent and prime position among the natural resources of the kingdom of Saudi Arabia. Although water is a renewable resource, yet its availability is extremely low and to the society. In the situation, there is a tremendous pressure on the existing water resources due to an 
increase in population, and the rising living standards of the civil society [9, 10, 15]. Although water is a renewable resource, yet its availability is extremely low and to the society. In the situation, there is a tremendous pressure on the existing water resources due to an increase in population, and the rising living standards of the civil society. Stress on water resources of kingdom has been further multiplied due to agricultural development and has led to their partial depletion, particularly in the case of non-renewable fossil water which is the main source of fresh water supplies. Reported that the desire to practice desert agriculture elevated the volume of water used for irrigation from about $6.8 \mathrm{~km} 3$ in 1980 to about $21 \mathrm{~km} 3$ in 2006. Further it was noticed that most of the water withdrawn came from fossil; deep aquifers [10]. In the kingdom, some predictions or estimates are made on the presence of water resources that they may not last more than 25 years. Water is a scarce natural resource that ensures human, plant and animal life. This vital and essential resource needs to be managed in a manner that rationalizes its consumption and secures its supply for future generations. The demand for water is increasing quite rapidly against the low and diminishing water resources.

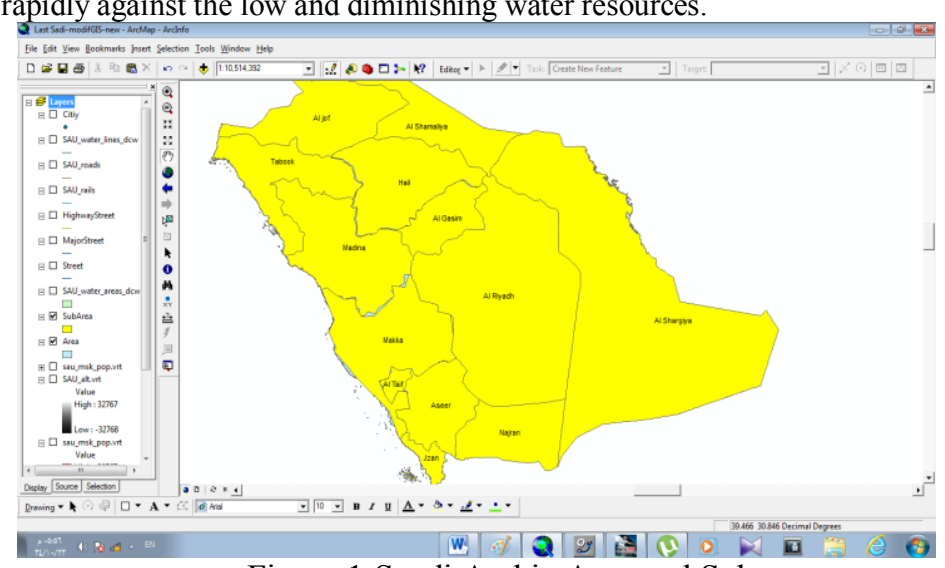

Figure 1:Saudi Arabia Area and Subareas

Consequently, it seems imperative to encourage the rational consumption of water and its management by all sectors on a scientific basis to ensure its continued availability and future conservation. Furthermore, there is a need to develop appropriate water quality standards and to enforce rules and regulations relating to these standards. The advanced technologies (such as cloud physics to increase the amount of rain) are needed to develop water resources and measures are to be taken to improve the recharge efficiency of ground water [16]. In this paper, an attempt has been made to review the available water resources of the country and possibly tailor the measures to be adopted to consume them efficiently and conserve this precious resource with the national spirit.

$<\ldots>$

$<$ Fid $>$ ObjectId $</$ Fid $>[1]$

$<$ Shape $>$ Ploygone $</$ Shape $>$ [1]

$<$ F_Code_Desc $>$ Text $</ F$ F_Code_Desc $>$ [1]

$<$ SübAreaName $>\underline{\text { Text }}</$ SubAreaName $>$ [1]

$<$ SubPopulation $>$ Integer $</$ SubPopulation $>$ [1]

$</ \ldots>$

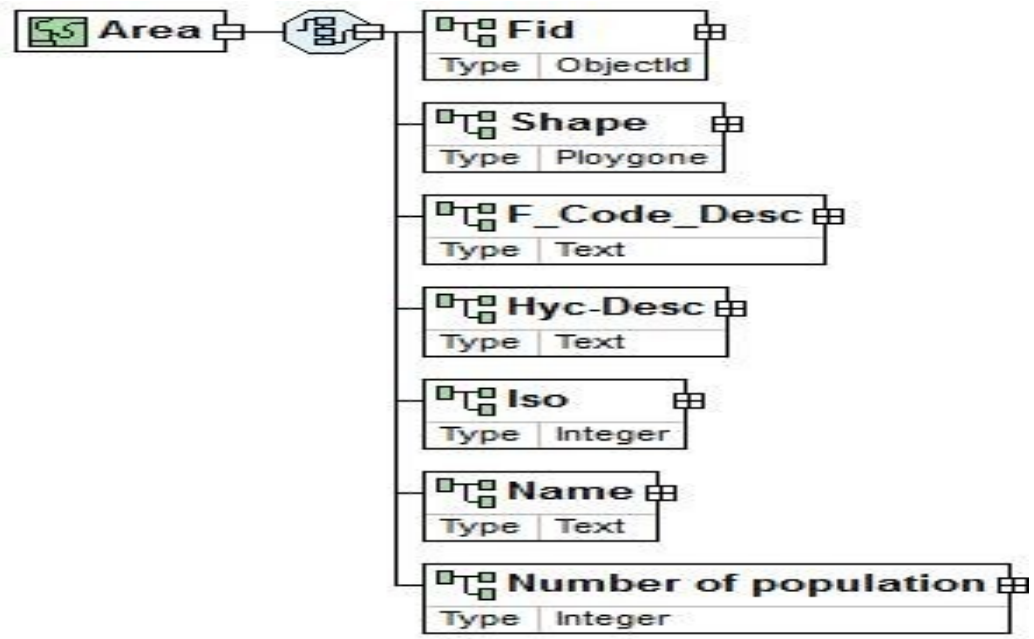

Figure 2: XML Instance Representation of Subarea 


\section{Water Resources and Their Uses}

- Saudi Arabia owns a limited renewable Water Resources, but Allah gave the kingdom a great deal of nonrenewable reserves of groundwater.

- The total volume of renewable resources and non-conventional resources including desalinated water and treated wastewater amount to 5.20 billion cubic meters (BCM)

- The Kingdom uses annually: $15.97 \mathrm{BCM}$ of water for irrigation purposes $2.42 \mathrm{BCM}$ of water for municipal purposes $0.80 \mathrm{BCM}$ of water for industrial purposes.

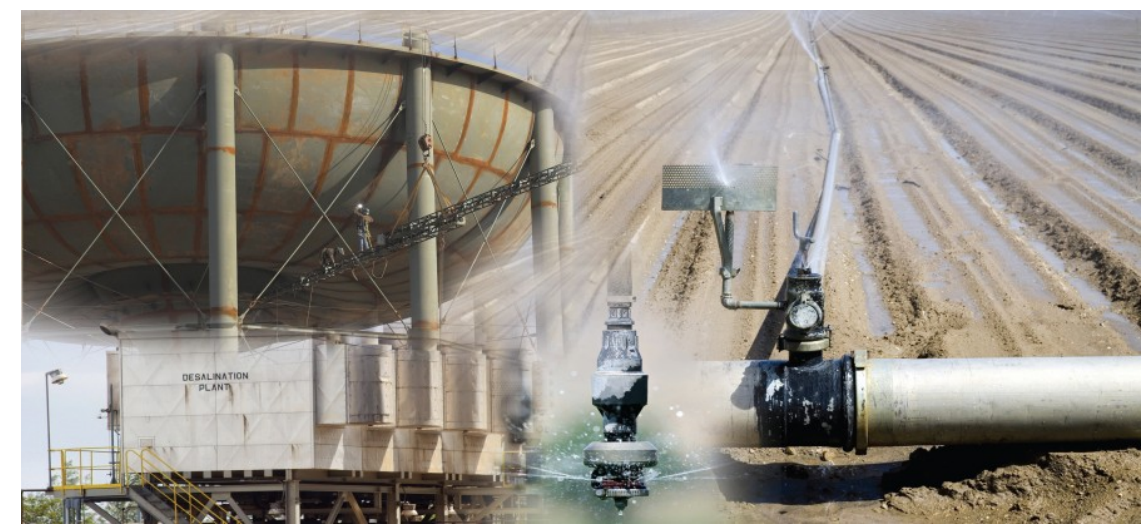

\subsection{Strengths}

- The water sector is the 5th largest recipient of Foreign Direct Investment in Saudi Arabia.

- The Saudi Government has consistently increased spending and investments in the water sector.

- As a country, Saudi Arabia is the 3rd largest consumer of water in the world, according to the

- Saudi Arabian Monetary Agency.

- As a country, Saudi Arabia is the largest producer of desalinated water in the world.

- The Saudi Government has streamlined the water sector's regulatory regime.

- The Saudi Government has put in place an extensive water transmission system.

\subsection{Weaknesses}

- An average of $20 \%$ of distributed water is unaccounted for in Saudi Arabia.

- The water sector's infrastructure is outdated and, in some areas, deteriorating.

- The Saudi Government's low water tariffs serve as a disincentive for conservation.

\subsection{Opportunities}

- Privatization and liberalization of the Saudi economy present numerous investment opportunities in the water sector.

- Accession into WTO has fostered an improved investment environment by lowering barriers to trade and tariff rates.

- $\quad$ Large government revenue generated from high oil prices will likely be invested in new development projects including those in the water sector. 


\subsection{Threats}

- Challenges associated with debt financing resulting from the global economic downturn may slow the rate of sector privatization.

- The perception of Saudi Arabia as a high security risk has, at times, deterred potential investors.

- Saudi Arabia's dependence on oil for government revenue means public spending and investment could be disrupted by a severe shock in the oil market.

With a population forecast to reach 29.3 million by 2015, the supply of fresh water is essential to Saudi Arabia, a desert country with a large agricultural and industrial base[18-25]. As the largest country in the world without running surface water, Saudi Arabia has been dependent on desalinated water for potable water since the 1950s. Today, Saudi Arabia is the world largest producer of desalinated water and home to the Marafiq complex in Jubail, the world's largest independent water and power project (IWPP). Moreover, Saudi Arabia will soon have one of the world's largest water pipelines, a more than 900-kilometer transmission system that will pump nearly 4 million cubic meters per day (cum/d) of water from Jubail Industrial City to the capital of Riyadh.

As water becomes an increasingly scarce resource, issues of water quality, quantity, management, and planning are essential for the future of the Kingdom's growing population. In addition to mounting demographics, industrialization and modernization have placed increasing pressure on Saudi Arabia's water infrastructure. Official sources indicate that an average of 20 percent of the Kingdom's water is unaccounted for due to a 25 year old infrastructure and resultant leakages. Further, a low tariff of only $\$ 0.027$ (SR0.10) per cubic meter of water that encourages non-rationalization of water consumption. Plans have been underway, however, to increase the water tariff to as much as $\$ 1.40$ (SR5) per cubic meter. These challenges have paved the way for the restructuring and gradual privatization of the Kingdom's water sector. The sector's privatization initiative will come in large measure through the establishments of public-private partnerships (PPPs) [25-30].

While the global economic downturn has recently led the Kingdom to bring a number of projects back under government control, Saudi Arabia recognizes that PPPs will remain instrumental in developing the industry and delivering water and wastewater services to residents throughout the country. The establishment of PPPs is expected to present a wealth of investment opportunities for U.S. companies engaged in this sector. Build-operate-transfer (BOT) will be a preferred method of PPPs with the private sector expected to finance design, build,

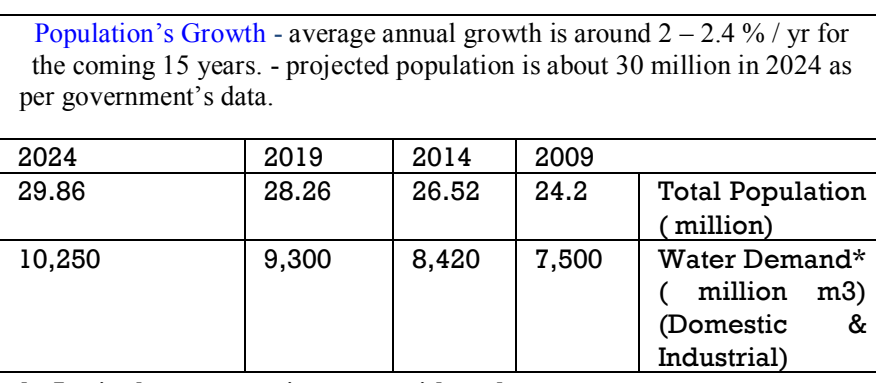

1- Agriculture usage is not considered

2- Current available desalination capacity is about 6,500 million $\mathrm{m} 3 / \mathrm{D}$ and operate the project for a specified period of time, after which ownership will be transferred back to the government. According to Samba Financial Group, the utilities sector, including electricity and water supply, is currently the fifth largest recipient of foreign investment in Saudi Arabia, and is expected to rise further in investor attractiveness over the next five years. The desalination, water, and sewage sector have already been earmarked as one of the sectors targeted for privatization for 2009. The Saline Water Conversion Corporation (SWCC), for example, is currently undergoing a largescale restructuring and privatization plan. The figure below show an assumption for Agricultural Purposes in the Kingdom of Saudi Arabia. Private investors and developers are already taking advantage of the opportunities that the sector's restructuring is offering. In 2008, the Ministry of Water and Electricity (MoWE) awarded more than 743 contracts worth over $\$ 3.1$ billion (SR11.9 billion). Moreover, the Saudi Government has resolved to continue developing the sector in the face of the economic downturn. While the global financial crisis has presented the Kingdom of Saudi Arabia with new challenges and has served to adjust a number of infrastructure projects, the Saudi Government views the development of the water sector as a matter of national importance. Stress on water resources of kingdom of Saudi Arabia has been further multiplied due to agricultural development and has led to their partial depletion, particularly in the case of non-renewable fossil water which is the main source of fresh water supplies. Reported that the desire to practice 
desert agriculture elevated the volume of water used for irrigation from about $6.8 \mathrm{~km} 3$ in 1980 to about $21 \mathrm{~km} 3$ in 2006. Further it was noticed that most of the water withdrawn came from fossil; deep aquifers $[10,15,17]$.

\section{Water Resources of the Kingdom}

The water resources in the Kingdom are divided into surface and underground deposits. Water collected through rainfall (surface water) is estimated to be about 2045 million cubic meters (MCM) per year. Depending upon rainfall, ground water is present in the basement crystalline rocks with an estimate of about 1.5 million cubic meters. The thickness of these rocks is about 500 meters. The production of the desalinated water reaches 740.52 million American gallons daily. In the kingdom, about 1.5 million cubic meters treated sewage water per day is also available, in addition about 32 million cubic meters per day the treated agricultural waste water is diverted to useful uses $[18,19,29]$.

\subsection{Kingdom Water From}

The Kingdom extracts its water from the following main sources:

Surface water is available with an estimate of about 2045 million cubic meters (MCM) per year comes from the rainfall, and is found predominantly in the west and south-west of the country. In 1985, surface water provided $10 \%$ of the kingdom's supply. While reporting on water resources, noted that total renewable surface water resources could be about $2.2 \mathrm{~km} /$ year in the kingdom of Saudi Arabia [10]. Reports that the annual runoff is estimated about $2230 \mathrm{MCM}$ in the kingdom [1,19, 29].

Ground water is found in the area of the basement rocks and the thickness of these rocks could be about $500 \mathrm{~m}$. ground water is held in aquifers, some of which are naturally replenished, while others are non-renewable. In 1985 , ground water provided $84 \%$ of the Kingdom's supply but it is noteworthy that most of this water was drawn from non-renewable aquifers. Similarly, also reported that the renewable groundwater resources were mainly stored in shallow alluvial aquifers and in basalt layers of varying thickness and width, and these aquifers mostly prevail in the southwest of the kingdom $[1,2,15]$.

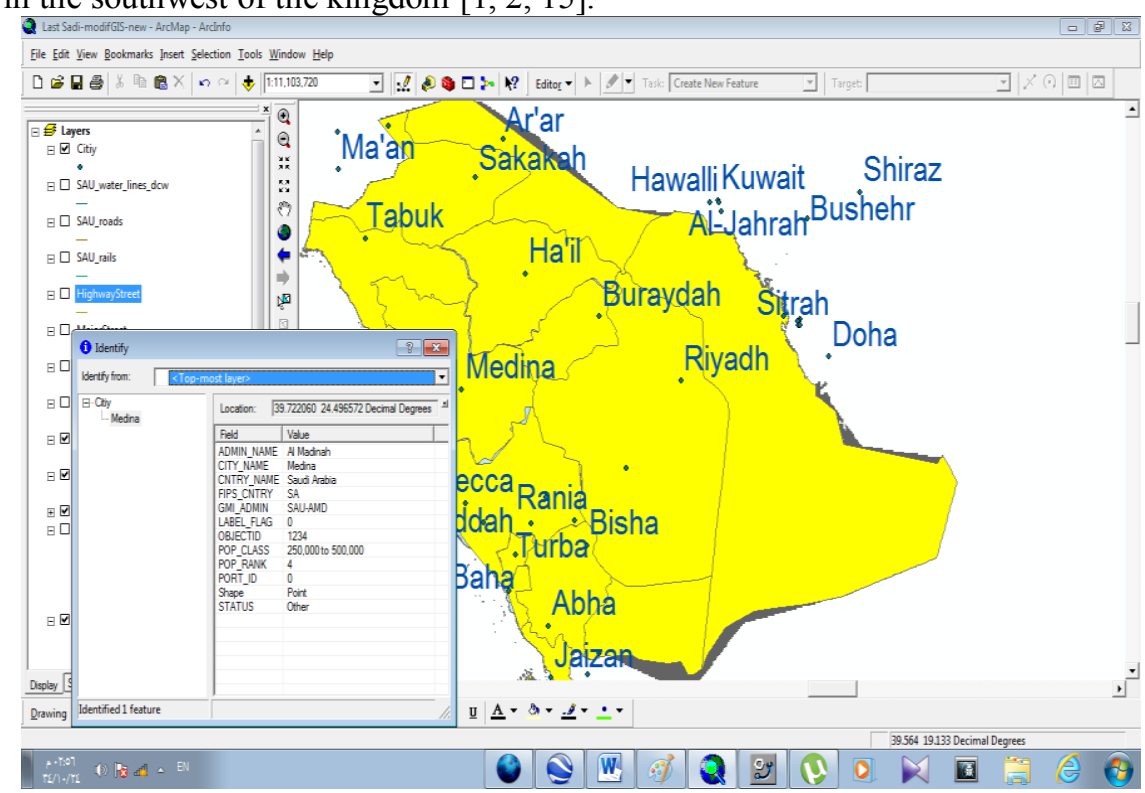

Figure 3: Instance Representation of Cities.

They are in a position to store some 84 billion cubic metres (BCM) with an average annual recharge of 1196 million cubic meters (MCM). More than twenty layered principal and secondary aquifers of different geological ages store groundwater $[12,15]$, and the quality of the groundwater varies at various sites and aquifers. Also maintains that total groundwater reserves (including) fossil groundwater) have been estimated to $500 \mathrm{~km}^{3}$. About $340 \mathrm{~km}^{3}$ out of this $500 \mathrm{~km}^{3}$ is drawn at an extremely high cost by the kingdom of Saudi Arabia. Estimates on available ground waters seem quite encouraging to meet the growing needs of the population of the kingdom [10]. Based on the isotopic analyses scientists believe that the fossil groundwater in these aquifers is ten to thirty-two thousand years old. At the depth of three hundred metres below ground surface about 2185 billion cubic metres groundwater is available with a total annual recharge of 2762 MCM [3, 8]. 


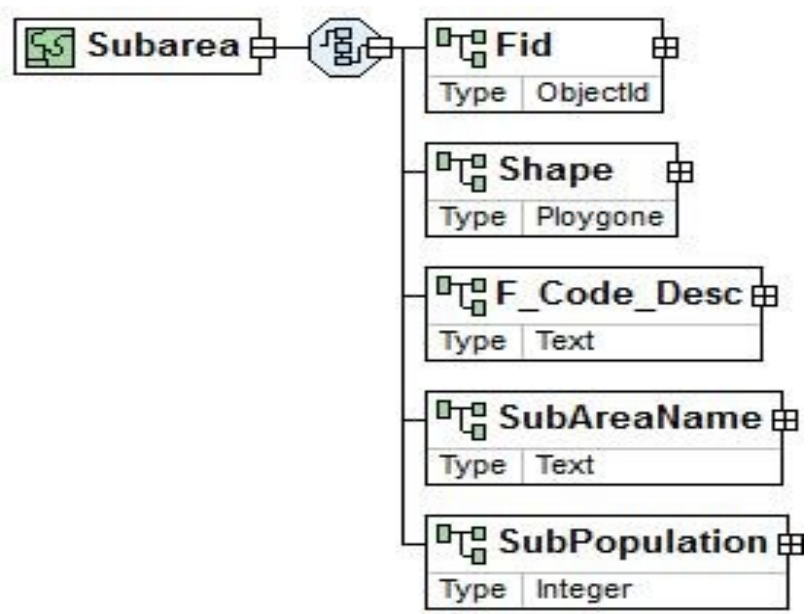

Figure 4: XML Instance Representation of Cities.

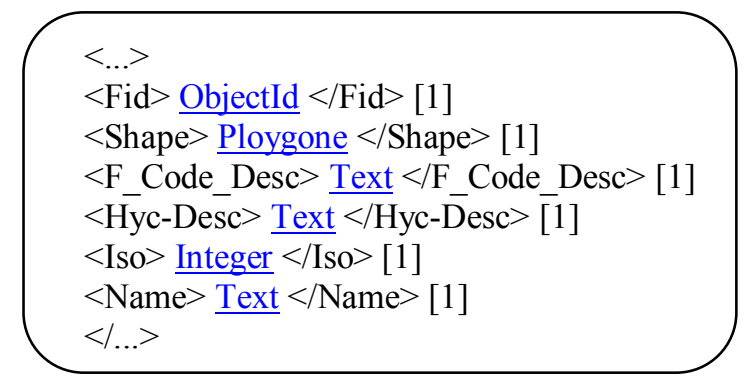

Desalinated seawater is the source of water production in which kingdom has emerged today as the world leader. Desalination technology, which also produces electricity, has reached an advanced stage of technology in the Kingdom and, by 1985; this source was providing 5\% of the Kingdom's supply. Reports that desalinated plants are providing more than 70 per cent of the required drinking water $[15,17,19]$. Reports that by 2010 [29], there were only 30 desalination and power plants in the country and in 2006 , about $1.03 \mathrm{~km}^{3}$ of desalinated water were produced. The total length of about $4156 \mathrm{~km}$ pipeline desalinated water is transmitted to various cities and the capacity of desalinated water reservoirs reached to $9.38 \mathrm{MCM}$ [10]. The water produced, is being used for municipal purposes.

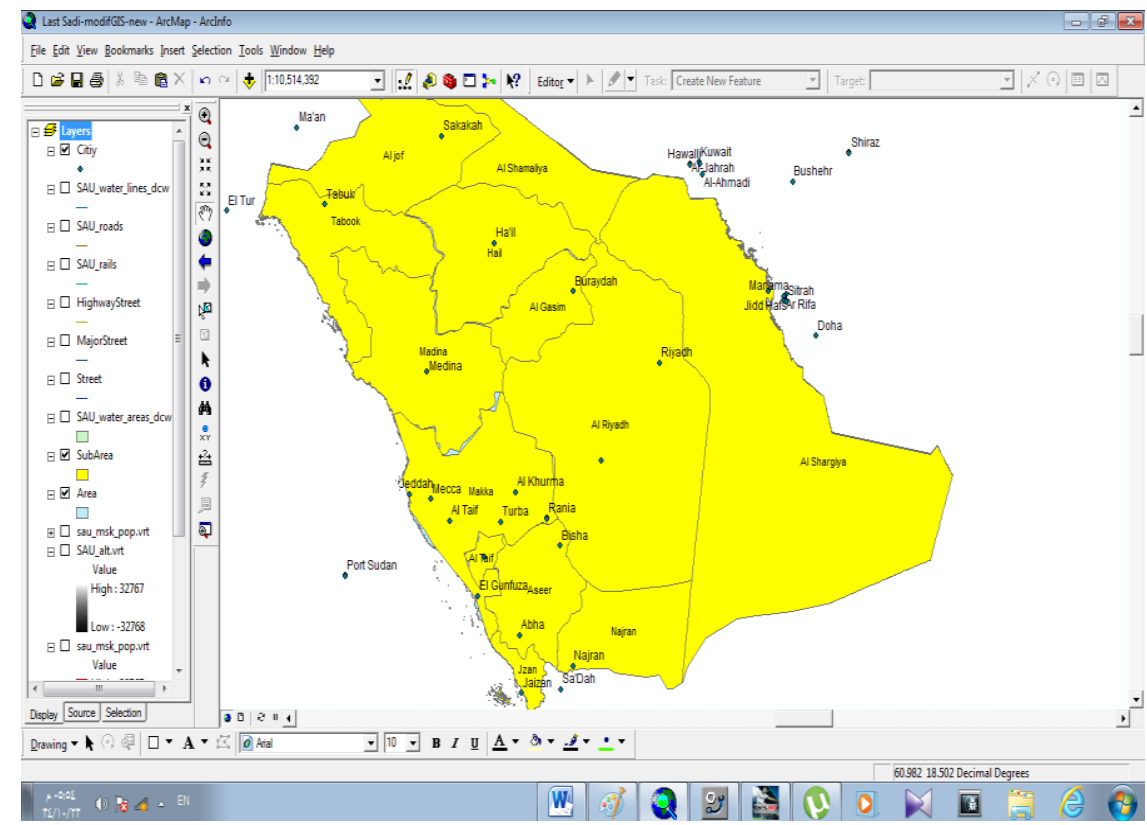

Figure 5: Saudi Arabia Main Cities. 


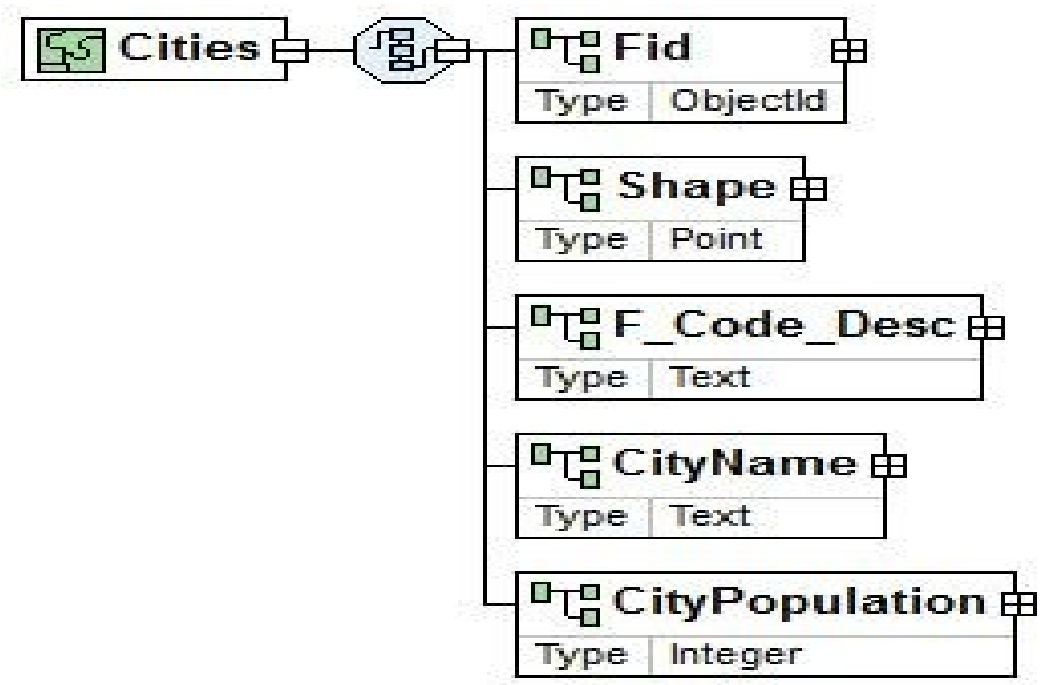

As reported by [1] that some 35 desalination plants have been built, with the cost of about 10 billion dollars, to produce potable water. By employing multistage flush system and reverse osmosis techniques, brackish sea water and raw groundwater from the Red Sea coast and the Arabian gulf coast are converted into drinkable forms [7]. He further noted these technologies and facilities helped Saudi Arabia becoming the largest producer of desalinized water in the world. On an average about $1050 \mathrm{MCM}$ desalinated water was produced only in the year 2000. According to [10] the quantities of desalinated water produced meet some 48 percent of the requirements of municipal uses. Although the cost of water associated with desalination units remains very high yet it is made available to the general public at a highly subsidized rate. Reported that the total water cost for one cubic metre of desalinized water is about SR 5.5 - 6.6 at the door step of the consumers. Still large-scale desalination plants were in a position to meet the 46 per cent of the household requirements and domestic demand for water $[1,19,29]$.

Reclaimed wastewater is obtained by treating agricultural waste water and it estimated to be about $32 \mathrm{MCM}$ per day. It is a source of water which is still in its early stages but offers a considerable potential for further expansion. Similarly, recycling of purified sewage water for agricultural and industrial use is taking place and the first project in this respect was established in the city of Riyadh and saves about $200000 \mathrm{~m}^{3}$ of purified water a day. According to reference [1], it is estimated that about $1000 \mathrm{MCM}$ of wastewater were generated in the country in 1996, and about 1500 MCM in the year [11]. About 41 per cent of municipal wastewater is treated, and in 1997, about $185 \mathrm{MCM}$ or 18.5 per cent of the treated wastewater was recycled for irrigating agricultural crops and landscape plants and for using in the refineries [1].

\subsection{Related Reports}

In addition, reports that total treated wastewater reached almost $548 \mathrm{MCM}$, of which $123 \mathrm{MCM}$ were reused. By the year 2003, some 70 sewage treatment plants were working and in operation [10]. No doubt, the idea is new and the use of treated waste water still did not hold enough ground as only $166 \mathrm{MCM}$ were being used in 2006, but it has got a very promising future in the kingdom for its multiple and beneficial uses. However, presently non-edible crops are irrigated with treated waste water. Different landscapes, gardens, parks also receive their irrigations with treated waste water, and for industrial cooling, they are equally good $[9,10]$.

Artesian Wells are being used for irrigating agricultural crops, human consumption and drinking purposes. To meet the water requirements of its population, more than 40810 artesian wells in addition to 52327 traditional wells have been drilled [14, 15, 19].

Dams collect rain and flood waters quite efficiently. In order to utilize these waters for useful purposes, the building of dams at various locations is of significant importance. Before 1975, there were only 16 dams in the kingdom; the number increased to 190 by 1999 and 223 by 2004, with the collective storage capacity of 836.6 MCM [10]. Today, there are more than 237 dams, with a total storage capacity of $775 \mathrm{MCM}$, for groundwater recharge and flood control. King Fahd Dam, the biggest one in Bisha Valley with a capacity of 325 MCM and was built in 1997 [14]. These dams store flood and storm water and in turn dams increase subterranean water reserves and enhance the availability of potable water. They protect the vegetation and plantations and some villages against the fast flows of flood waters as sudden torrential rises used to be the big threats in the past. 


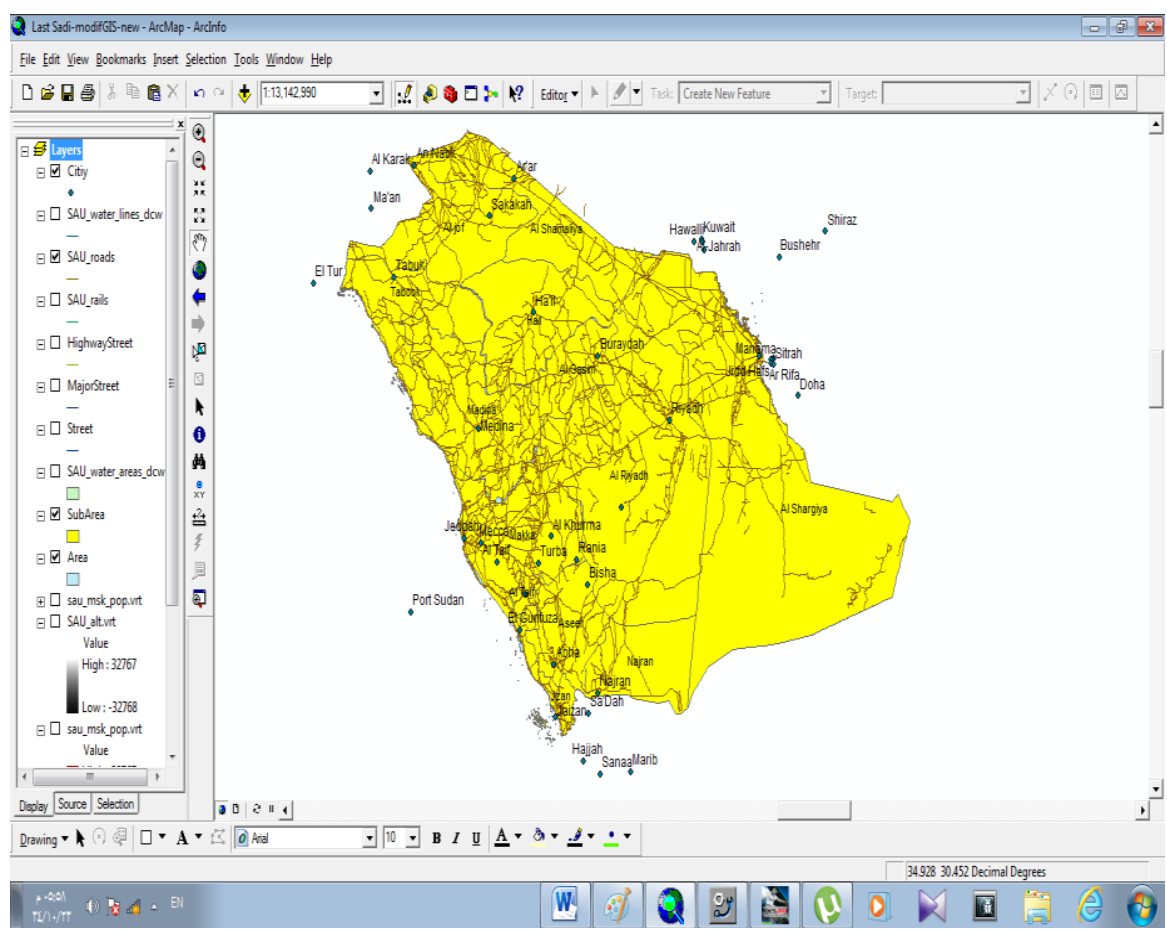

Figure 6: Saudi Arabia Roads shape File

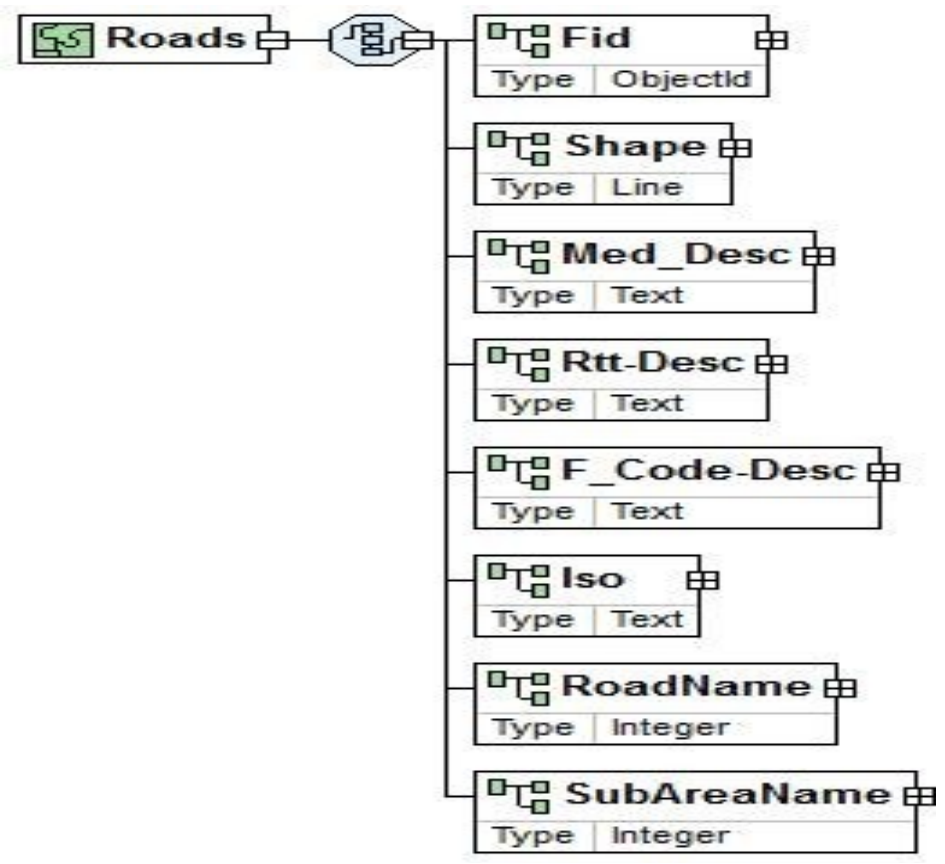

Figure 7: XML Instance Representation of Rail Roads.

$<$ Fid $>$ ObjectId $<$ Fid $>$ [1]

$<$ Shape $>\underline{\text { Line }}</$ Shape $>[1]$

$<$ Med_Desc $>$ Text $<$ Med_Desc $>$ [1]

$<$ Rtt-Desc $>$ Text $</$ Rtt-Desc $>[1]$

$<$ F_Code-Desc $>$ Text $</$ F_Code-Desc $>[1]$

$<$ Iso $>$ Text $</$ Iso $>[1]$

$<$ RailName $>$ Integer $</$ RailName $>$ [1]

$<$ SubAreaName $>$ Integer $</$ SubAreaName $>$ [1]

$</ \ldots>$ 


\section{Development Of Water Demand Management}

The available surface water and groundwater resources are limited, precipitation rates are low, evaporation rates are high, and most part of the Kingdom lies in arid regions. All these factors make the kingdom a water shortage and deficit state. An average annual rainfall is less than $150 \mathrm{~mm}$ in most parts of the country [10]. Due to the comprehensive development realized in all sectors, today the annual national water demand in the kingdom has exceeded 30000 MCM [1] as revealed in Tables 1 and chart figure below. In the kingdom supply aspect received attention, whereas demand management remained un-noticed, despite of its improved and enhanced potential benefits.

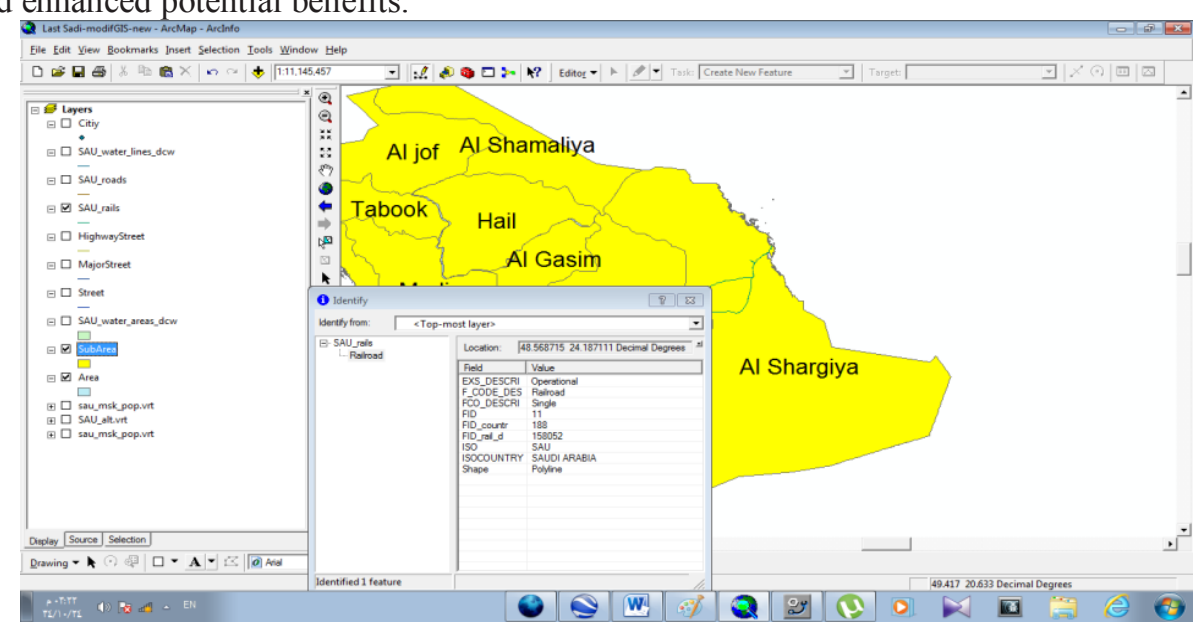

Figure 8: Saudi Arabia Railroads only between Riyadh and Al Shargiya Areas.

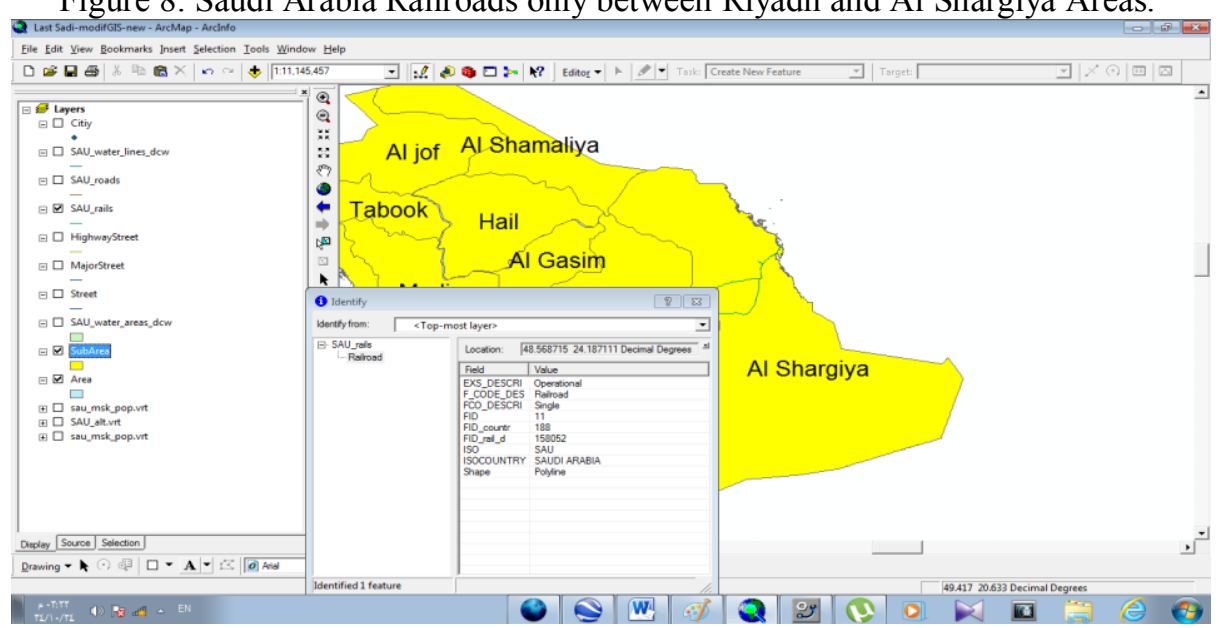

Figure 9: Saudi Arabia Railroads only between Al Shamaliya and Shargiya Areas

\begin{tabular}{|c|c|c|c|c|c|}
\hline Status & $\begin{array}{c}\text { \% of KSA total } \\
\text { potable water } \\
\text { supply }\end{array}$ & $\begin{array}{c}\text { Daily potable } \\
\text { water supply } \\
\text { (M3/day) }\end{array}$ & $\begin{array}{l}\% \text { of KSA } \\
\text { population }\end{array}$ & Population & City \\
\hline Finalized & $28 \%$ & $1,403,293$ & $18.35 \%$ & $4,583,764$ & Riyadh \\
\hline Finalized & $12 \%$ & 626,173 & $12.29 \%$ & $3,068,485$ & Jeddah \\
\hline \multirow{3}{*}{$\begin{array}{l}\text { Consultants } \\
\text { Appointed } \\
\text { Tendering } \\
\text { process will } \\
\text { start soon }\end{array}$} & $11 \%$ & 528,445 & $4.82 \%$ & $1,203,839$ & Greater Dammam \\
\hline & $6 \%$ & 281,333 & $3.98 \%$ & 994,175 & Madinah \\
\hline & $2 \%$ & 116,184 & $3.09 \%$ & 771,123 & Taif \\
\hline \multirow{3}{*}{ Under Study } & $4 \%$ & 189,111 & $2.27 \%$ & 567,427 & Buraida \& Onaizah \\
\hline & $1 \%$ & 67,362 & $2.57 \%$ & 642,821 & $\begin{array}{l}\text { Khamis mushayat \& } \\
\text { Abha }\end{array}$ \\
\hline & $76.17 \%$ & $3,817,091$ & $59.58 \%$ & $14,878,473$ & Total (15 cities) \\
\hline
\end{tabular}

Table 1: Cities Targeted for privatization. 


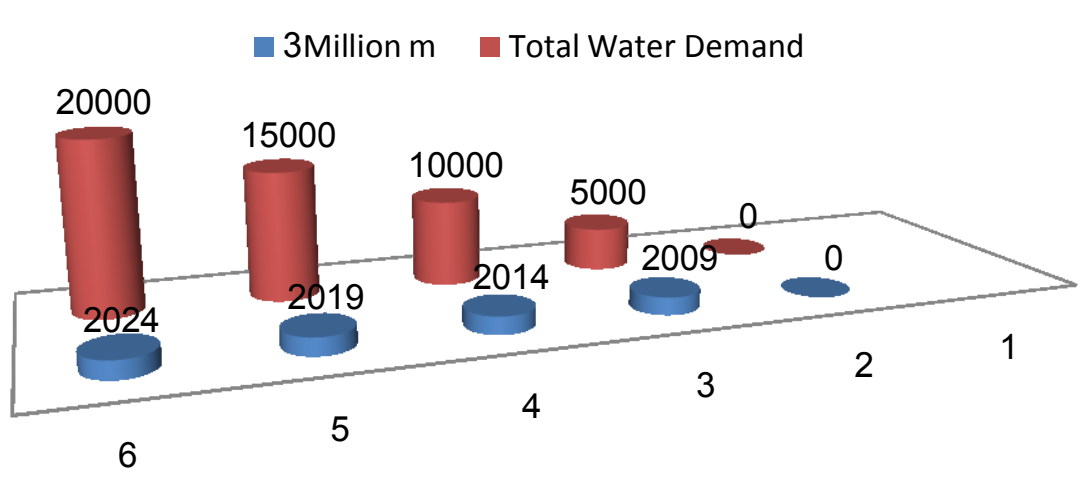

Chart Figure for Total Water Demand in KSA.

\subsection{Water Demand Management}

At present the concept of Water Demand Management (WDM) is slowly gaining recognition and popularity as an essential complement to supply management if fresh water is to be used in a sustainable manner [6-10].

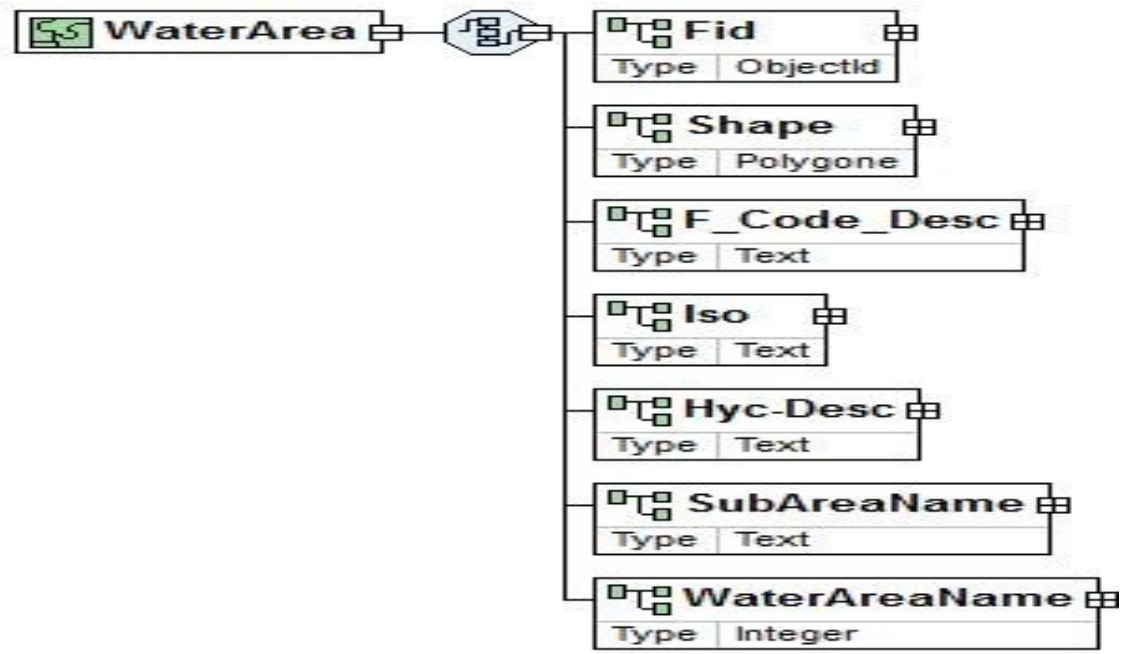

Figure 10: XML Instance Representation of water area.

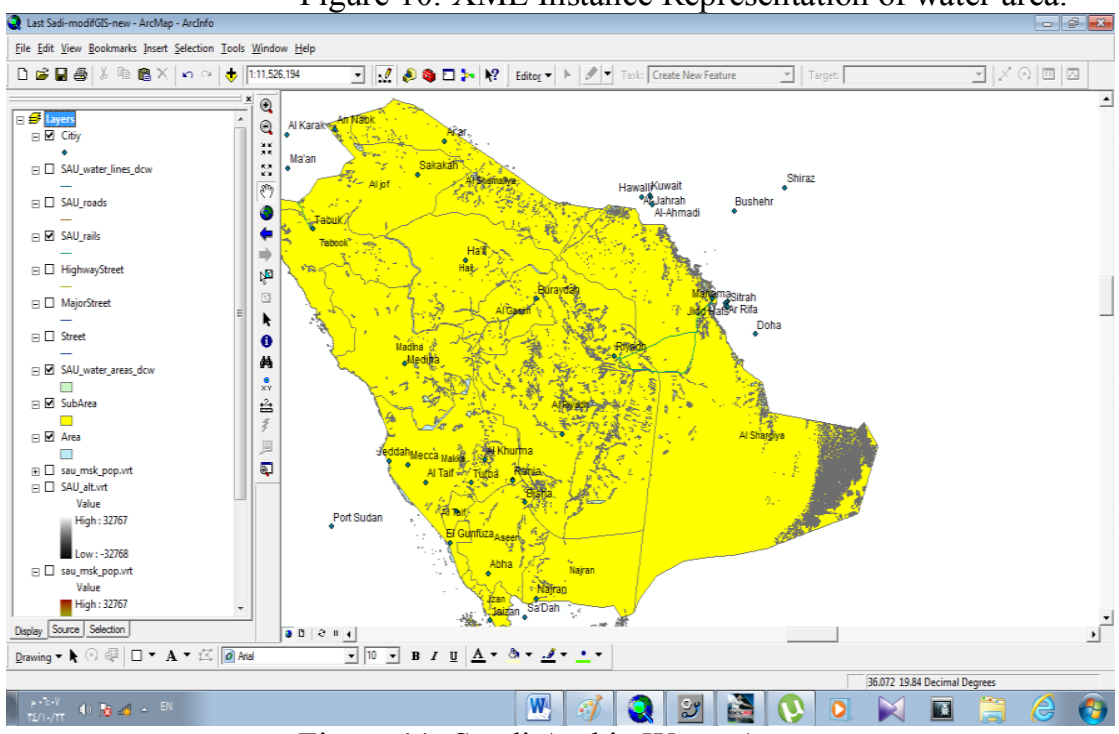

Figure 11: Saudi Arabia Water Areas 


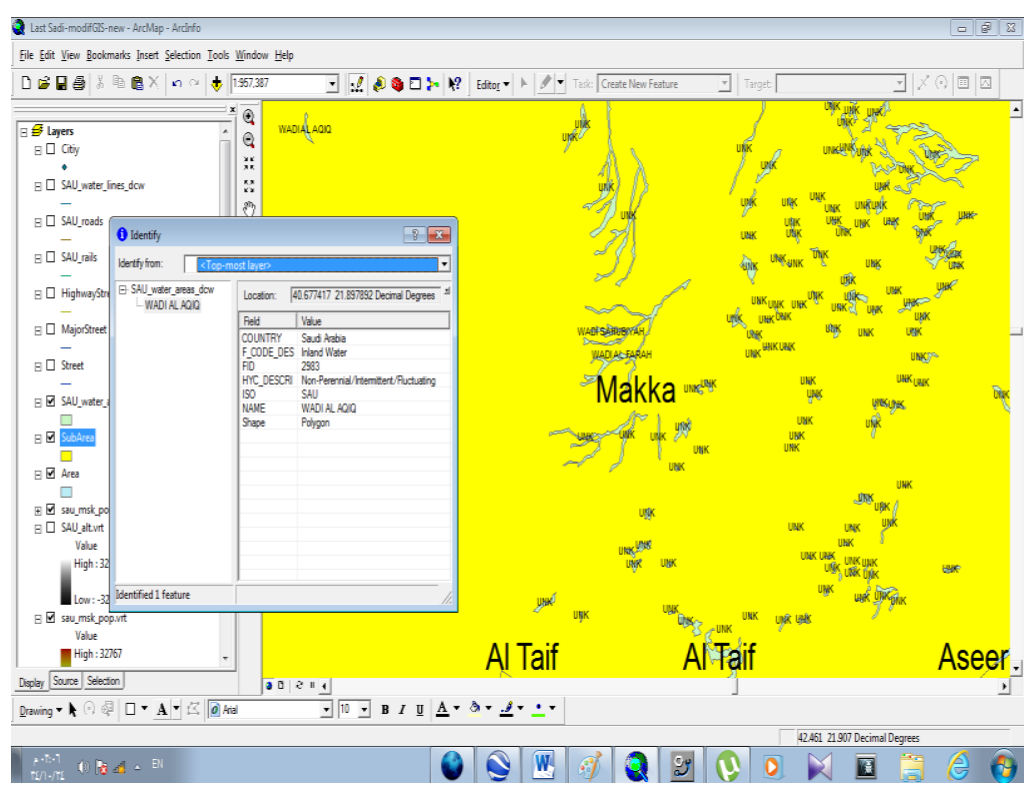

Figure 12: Wadi Alaqiq on Makkah Area

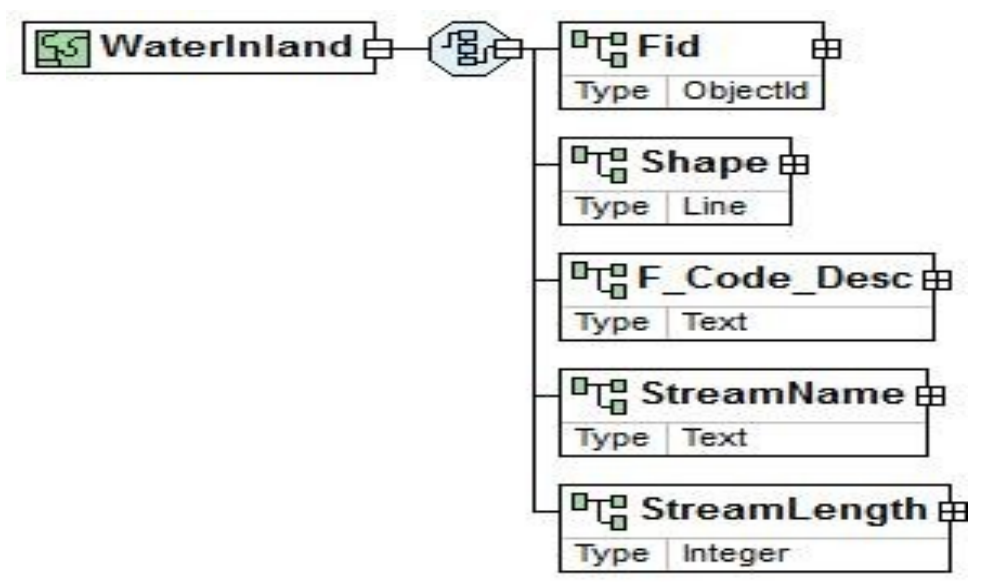

Figure 13: XML Instance Representation of water Inland

$<\ldots>$

$<$ Fid $>\underline{\text { ObjectId }}</$ Fid $>[1]$

$<$ Shape $>$ Line $</$ Shape $>[1]$

$<$ F_Code_Desc $>$ Text $</$ F_Code_Desc $>[1]$

$<$ StreamName $>$ Text $</$ StreamName $>[1]$

$<$ StreamLength $>$ Integer $</$ StreamLength $>[1]$

$</ \ldots>$

While WDM showed many economic benefits by increasing efficiency as well as, in

$<$ Fid $>$ ObjectId $<$ Fid $>[1]$

$<$ Shape $>$ Polygone $</$ Shape $>$ [1]

$<$ F_Code_Desc $>$ Text $</$ F_Code_Desc $>[1]$

$<$ Iso $>$ Text $<$ Isso $>$ [1]

$<$ Hyc-Desc $>$ Text $</$ Hyc-Desc $>$ [1]

$<$ SubAreaName $>$ Text $<$ SubAreaName $>$ [1]

$<$ WaterAreaName $>$ Integer $</$ WaterAreaName $>$ [1]

$</ \ldots>$ 


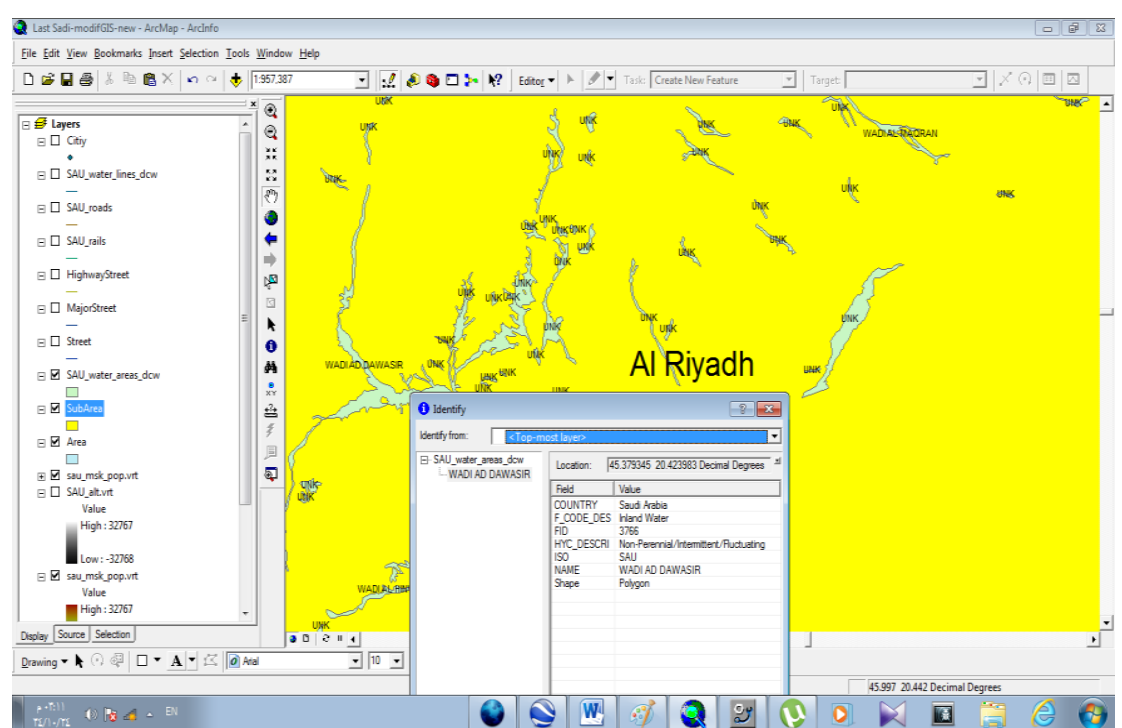

Figure 14:Saudi Arabia Water in land streams

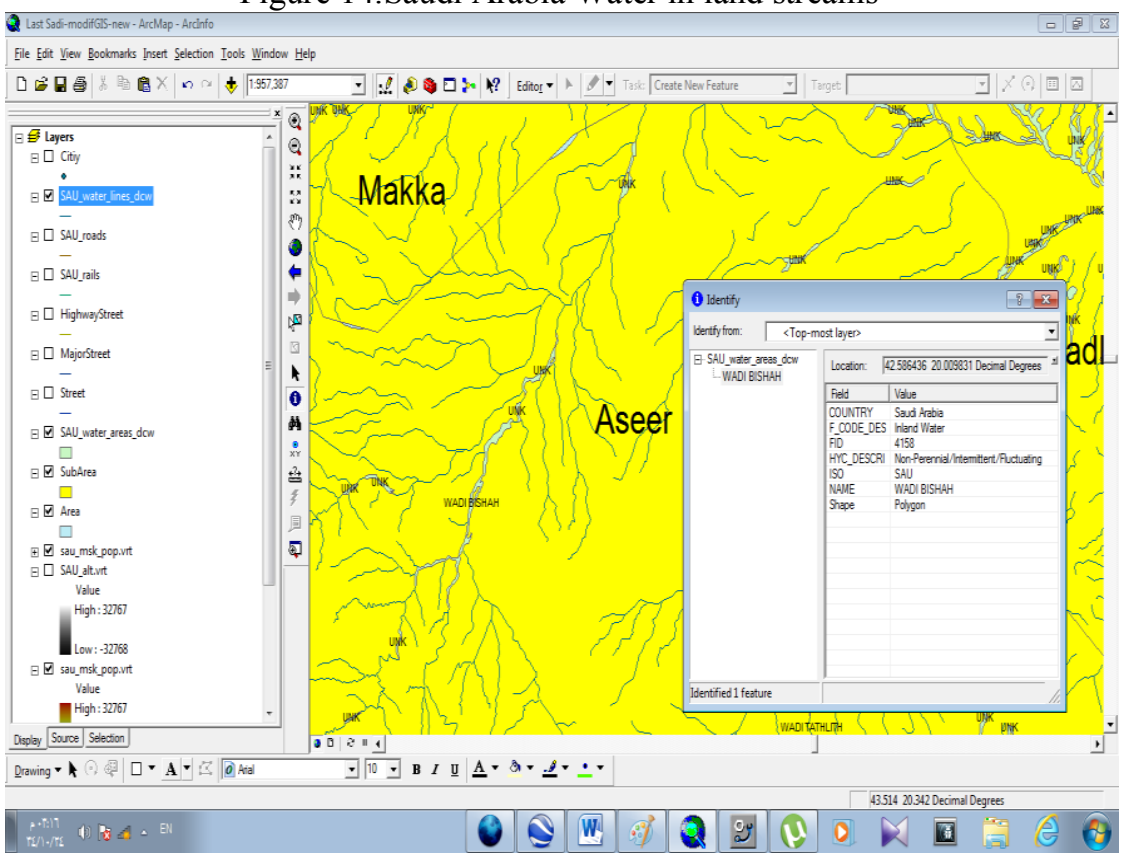

Figure 15: Saudi Arabia Representation of Land Cover

$<\ldots>$

$<$ Fid $>$ ObjectId $<$ Fid $>[1]$

$<$ Shape $>$ Line $</$ Shape $>[1]$

$<$ Med_Desc $>$ Text $<$ Med_Desc $>$ [1]

$<$ Rtt-Desc $>$ Text $<$ Rtt-Desc $>$ [1]

$<$ F_Code-Desc $>$ Text $</$ F_Code-Desc $>[1]$

$<$ Iso $>$ Text $<$ Isso $>$ [1]

$<$ LandName $>$ Integer $</$ LandName $>[1]$

$<$ SubAreaName $>$ Integer $</$ SubAreaName $>$ [1] 


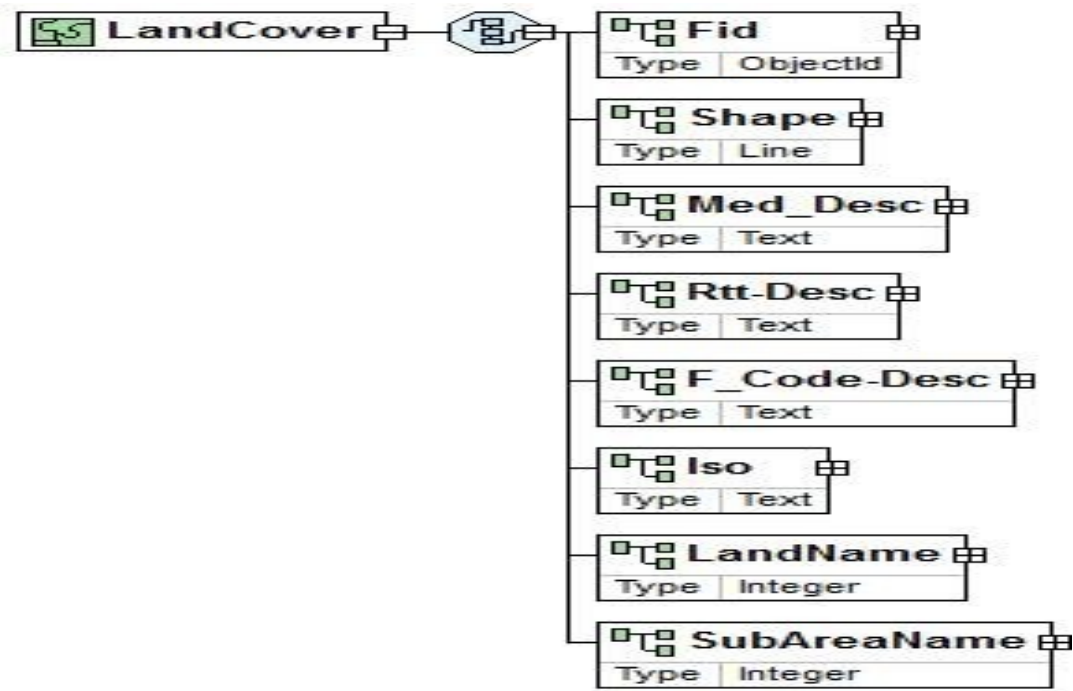

Figure 16: XML Instance Representation of Land Cover

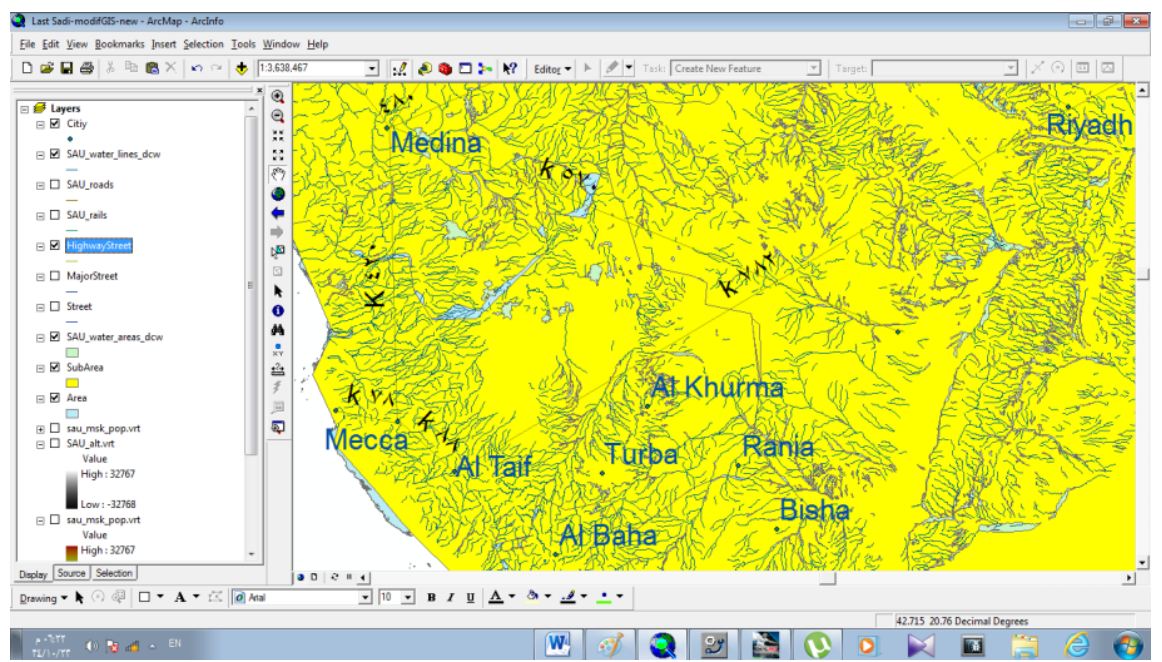

Figure 17: XML Instance Representation of Elevation

$<$ Fid $>$ ObjectId $<$ Fid $>[1]$

$<$ Shape $>$ Line $</$ Shape $>[1]$

$<$ Med_Desc $>$ Text $<$ Med_Desc $>$ [1]

$<$ Rtt-Desc $>$ Text $</$ Rtt-Desc $>[1]$

$<$ F_Code-Desc $>$ Text $<$ F_Code-Desc $>[1]$

$<$ Iso $>$ Text $</$ Iso $>[1]$

$<$ ElevationType $>$ text $</$ ElevationType $>[1]$

$<$ SubAreaName $>$ Integer $</$ SubAreaName $>$ [1]

$</ \ldots>$ 


\subsection{Wastewater Sector Overview}

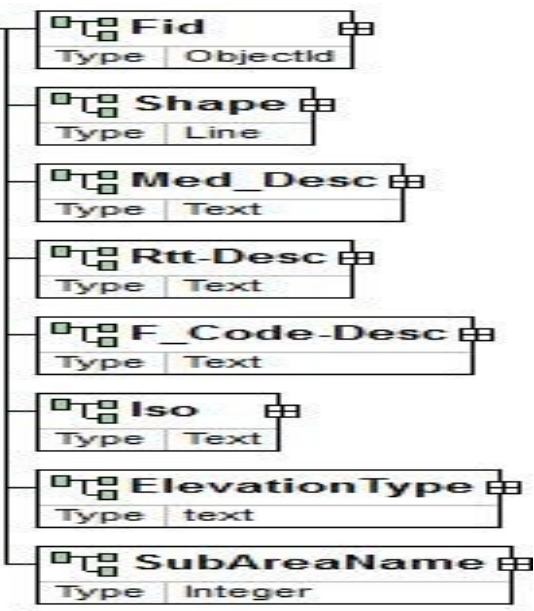

- more water consumption leads to increase in wastewater that require treatment

- approximately $45-55 \%$ of the wastewater in KSA is treated

- approximately $40 \%$ of the wastewater produced in KSA is collected by network. The balance is collected in septic tanks; then some of it is collected by trucks to be dumped in artificial lagoons or in WWTPs

- approximately $18 \%$ of TSE is used

- water reuse accounts for $1 \%$ of KSA's total water supply

\subsection{Challenges, Opportunities \& Investment}

Opportunities are open in water \& wastewater treatment projects:

A- Water Segment

- Brackish \& sea water treatment

- plants

- Water networks

- Reservoirs

- Deep well drilling

- Rehabilitation of existing plants

- This would be through:

\begin{tabular}{|l|l|l|}
\hline $\begin{array}{l}\text { Se } \\
\text { q. }\end{array}$ & $\begin{array}{l}\text { Capacity } \\
\text { M3/D }\end{array}$ & City \\
\hline 1 & 550,000 & Yanbu 3 \\
\hline 2 & 650,000 & Shouibah 4 \\
\hline 3 & 175,000 & Shuqaiq 3 \\
\hline 4 & 250,000 & Khobar 4 \\
\hline 5 & 78,000 & Jubail RO (Upgrade) \\
\hline 6 & 29,000 & Al Waji/ Duba/ Haql \\
\hline 7 & 70,000 & KAEC \\
\hline 8 & 12,000 & Jizan Economic City \\
\hline 9 & 30,000 & Al Khafji \\
\hline \multicolumn{2}{|c|}{ Forthcoming Projects- Water } \\
\hline
\end{tabular}

- $\quad$ EPC, PPP, IWPP, BOT, BOOT etc.

B- Waste water Segment

- Wastewater treatment plant

- Networks

- Lift stations

\begin{tabular}{|c|c|c|}
\hline Seq. & $\begin{array}{c}\text { Capacity } \\
\text { M3/D }\end{array}$ & City \\
\hline 1 & 200,000 & Al- Kharij STP- Ph3 \\
\hline 2 & 250,000 & Jeddah - Airport Ph2 \\
\hline 3 & 250,000 & Jeddah- AlKhumra Ph- 4 \\
\hline 4 & 250,000 & Jeddah- Al Khumra Ph- 5 \\
\hline 5 & 200,000 & Maddinah \\
\hline 6 & 30,000 & Al- Kharij STP- Ph3 \\
\hline \multicolumn{3}{|c|}{ Forthcoming Projects - Wastewater } \\
\hline
\end{tabular}


- Sludge treatment

- Reuse of TSE

- Rehabilitation of existing

\section{Google earth for showing the elevations in Saudi Arabia}

As shown in figures 16 and 17 illustrates the Instance Representation of Elevation in Saudi Arabia subareas in major cities. XML Instance Representation of Elevation as shown in figure 17.
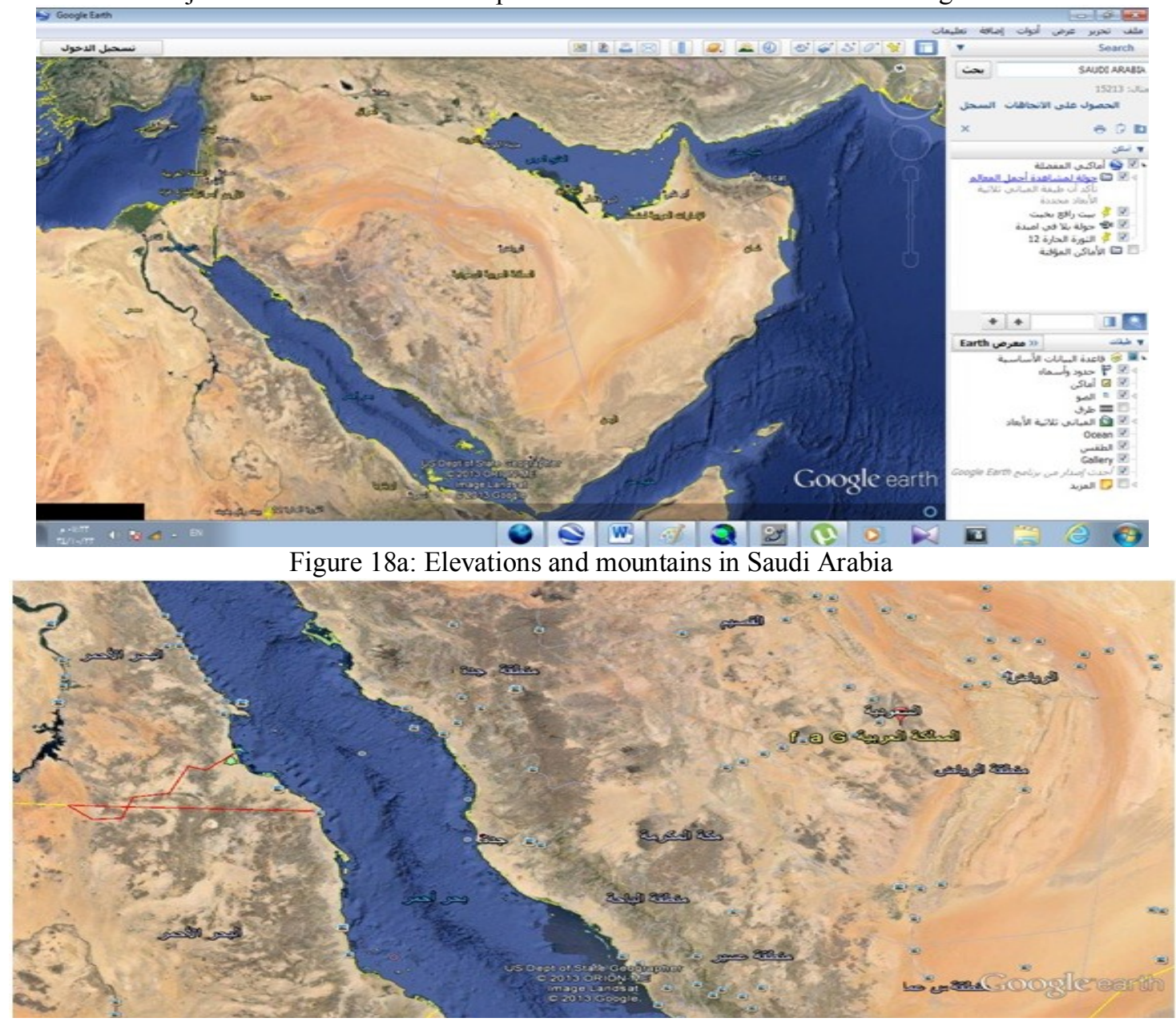

Figure 18b: Elevations and mountains in Makkah and Madinah Areas. Progress of Management of Demand-Water

\begin{tabular}{|c|c|c|c|c|}
\hline City & Population & $\begin{array}{c}\text { Percentage of KSA } \\
\text { Population } \\
\%\end{array}$ & $\begin{array}{c}\text { Daily potable water } \\
\text { supply }\left(\mathrm{M}^{3} / \text { day }\right)\end{array}$ & $\begin{array}{c}\text { Percentage of KSA total } \\
\text { potable water supply }\end{array}$ \\
\hline $\begin{array}{c}\text { Greater } \\
\text { Dammam }\end{array}$ & $1,203,839$ & $4.82 \%$ & 528,445 & $11 \%$ \\
\hline Madinah & 994,175 & $3.98 \%$ & 281,333 & $6 \%$ \\
\hline Makkah & $1,424,945$ & $5.71 \%$ & 201,530 & $4 \%$ \\
\hline
\end{tabular}

\begin{tabular}{|c|c|c|c|}
\hline City & Pre_Qualification & $\begin{array}{c}\text { Tentative date for RFP } \\
\text { Release }\end{array}$ & Daily potable water supply ( $\mathrm{M}^{3} /$ day $)$ \\
\hline Greater Dammam & \multirow{3}{*}{ July 2009} & Sep 2009 & \multirow{3}{*}{$\begin{array}{c}\text { Will be completed by } 2010 \text { in a } \\
\text { phased manner }\end{array}$} \\
\hline Madinah & & Nov 2009 & \\
\hline Makkah & & Jan 2010 & \\
\hline
\end{tabular}


Grand total Water-Demand per day $: 2,090,000 \mathrm{M}^{3} / \mathrm{day}$

\section{Expected TSE Demand (M3/day) Sector}

\begin{tabular}{|cl}
\hline $1,350,000$ & Agriculture \\
300,000 & Environmental \\
220,000 & Commercial \\
120,000 & Industrial / District cooling \\
100,000 & Municipal \\
$2,090,000$ & Total
\end{tabular}

Many cases, greater equity, reduced environmental damage, and helped increasing greater public participation. Water demand management can be defined as any method-whether technical, economic, administrative, financial or social - is capable of accomplishing one (or more) of the following five components:

- $\quad$ Reduce the quantity or quality of water required to accomplish a certain and specific task;

- Adjust the nature of the task or the way it is undertaken so that it can be accomplished with less water or with lower quality water;

- $\quad$ Reduce the loss in quantity or quality of water as it flows from source through use to disposal;

- $\quad$ Shift the timing of use from peak to off-peak periods;

- Increase the ability of the water system to continue to serve the communities when water availability is low and at times of shortage of water.

\subsection{Google earth for showing the elevations in Saudi Arabia Areas}

As shown in figures 18a and 18b illustrates Google earth for showing the elevations in Saudi Arabia subareas in major cities such as Makkah and Madinah Areas. The following regions use Aquifers storage for water supply: Riyadh, Qasim, Madinah, Eastern Province, Hail, Tabuk, Northern Borders, Najran, Asir and Al-Jouf.

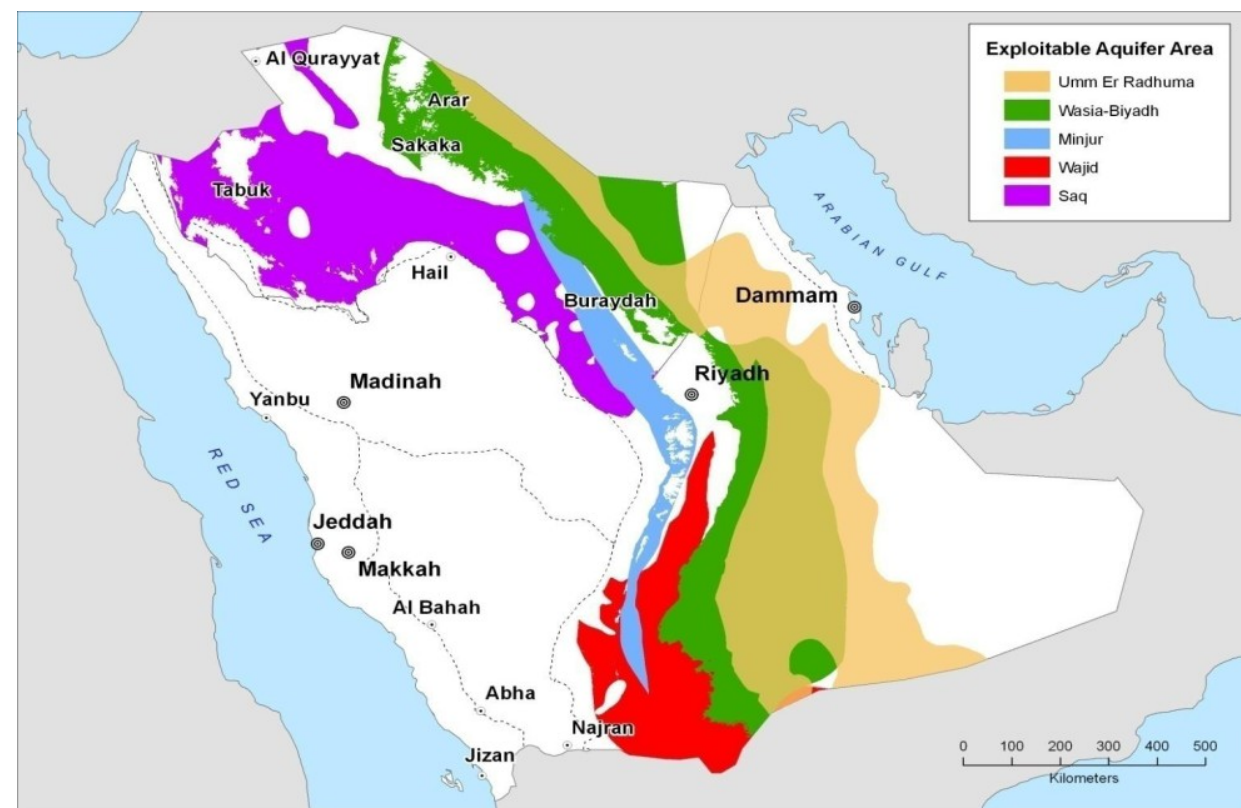

The abstracted water from Saq, Umm Erudhuma, Wajeed, Minjure Aquifers amount to (B13.8 BCM/year which constitutes $90 \%$ of non-renewable water use in the Kingdom and equal 6 times of municipal water consumption [20-30]. 


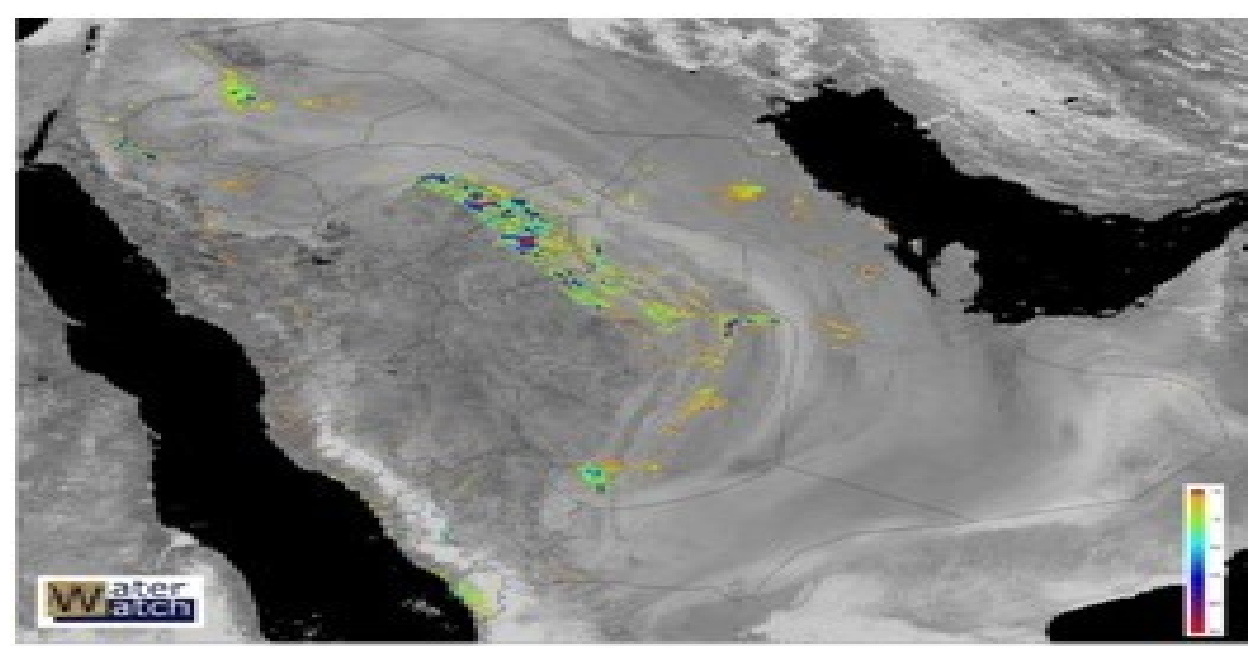

\subsection{Main Challenges of Water Sector}

Currently, The KSA faces three major challenges:

1.Water depletion is threatening the nation's future.

2.Saudi Arabia's agriculture sector is not sustainable nor efficient.

3.Municipal water supply services are high cost and suboptimal quality.

\section{Recommendations on Water Conservation}

Has offered the whole set of recommendations for managing water for agriculture; however, a brief sketch is presented as under $[9,10,15]$ :

- There is a need for the strict policies for use of water and adoption of conservation measures.

- Agricultural management sector is the biggest consumer of water $(88 \%)$ and to keep its usage minimum better and improved irrigation methods and environmental enhancement farming technologies are needed. Agricultural sector consumption of Water reached 542 BCM from 1975. to 2010 G. which equal the production of (SWCC) for 500 years. $90 \%$ of Agricultural sector consumption of water concentrated in such areas as shown in the figure below.

To help farmers to grow drought resistant/ tolerant varieties crops and trees, continued research support is needed. Research initiatives on exploring new irrigation methods and improving the presently available irrigation methods to use the limited water resources efficiently and effectively are needed. There is a need to create awareness among the users in both rural and urban areas, persuading the users to adopt conservation measures and environmental enhancement technologies.

Training programs for the trainers and the users on the water demand management and its conservation should be arranged.

- The initiatives on the reuse of wastewater effluents especially for irrigation have been encouraged and now millions of cubic metres (MCM) of treated effluents have become available for this purpose. Similarly, recycling of treated industrial wastewater is another appreciable initiative, and has been implemented by various industrial plants [20-27].

- Surface irrigation systems should be replaced by drip, sprinkler irrigation and micro-irrigation systems.

- Promote the cultivation of crops with lower water requirements. There is a need of shifting of some of the

fodder and cereals areas from high water consumption zones to lower water consumption zones.

- Encourage farmers having water meters at the farm level to control of pumping of water.

- The initiatives taken by the kingdom of Saudi Arabia on water demand management have been successful in satisfying growing water needs and protecting water resources. This demonstrates that the programs launched by the state on the most vital and pressing issue of water are sufficiently dynamic, flexible, and reasonable enough to solve the challenges faced by the nation. Extension professionals need to promote and popularize them among the masses. It is stressed that the available environmental friendly technologies on the wise use of water be enlisted and be known to the end users through extension and education programs [24-30]. 
- The state regulations on the use of water, reduction in domestic water demand by the introduction of new water pricing policies, leakage detection and all other control measures that could conserve water must be applied with letter and spirit.

- Concerted efforts should be made by all the stake-holders working with the public on enhancing public awareness on the value of water.

\section{Conclusion}

This paper places emphasizes on the urgency of adopting conservation and water-demand management initiatives to maintain demand supply relationship and achieve an acceptable balance between water needs and availability. The kingdom of Saudi Arabia places emphasis on the shift from supply development to demand management to use of critical and non-renewable water resources efficiently. The paper suggests that the wateruse-efficiency (WUE) in various sectors can be enhanced and improved in the kingdom of Saudi Arabia. The paper presents an overview of the country's water resources and issues related to water. Some possible conservation and remedial measures particularly in the agricultural sector-the largest and most inefficient user of water have been suggested.

The objective of this paper is to safeguard and conserve this precious natural resource through environmental enhancement technologies for the future generations to come. It is presumed that water resources can be managed on sustainable basis by devising and employing environmental enhancement technologies including water conservation measures. Demand met by least cost sustainable supply with water use produces maximum social benefit and water security is assured. The usefulness of these measures can be supplemented through the vibrant and viable extension and education initiatives and capacity building programs. The paper presents an overview of the country's water resources and issues related to water. Some possible conservation and remedial measures particularly in the agricultural sector - the largest and most inefficient user of water have been suggested. Finally; Population growth is pushing for faster extraction rate than the replenishment rate which is leading to a decline in groundwater resources significant investment is required in desalination.

\section{References}

[1] Abderrahman, W. A., 2009. Water Demand Management In Saudi Arabia. (Chapter 6). Book Published By International Development Research Centre, Canada. Available At: Http://Www.Idrc.Ca/En/Ev-93954-201-1DO_TOPIC.Html.

[2] Abderrahman, W. A., 1997. The Use Of Closed Water Cycle In Industrial Plants In Saudi Arabia,” In Proceedings Of The Conference On Development And Environmental Impact. 21-23 September, Ministry Of Municipal And Rural Affairs, Riyadh.

[3] Al Alawi, M. And M. Abdulrazzak, 1994. Water In The Arabian Peninsula: Problems And Perspectives," In P. Rogers And P. Lydon (Eds.). Water In The Arab World: Perspectives And Progress, Division Of Applied Sciences, Harvard University, Cambridge, Mass.

[4] Al-Ibrahim, A. A., 1990. Water Use In Saudi Arabia: Problems And Policy Implications. Journal Of Water Resources Planning And Management, $116(3): 375388$.

[5] Al-Tukhais, A. S., 1997. Water Resources And Agricultural Production In Saudi Arabia: Present And Future. Proc. Water Resources And Its Utilization In Saudi Arabia: Proceedings Of The First Saudi Conference On Agricultural Sciences, $25-27$ March 1997, College Of Agric., King Saud University, Riyadh, KSA.

[6] Brooks, D. B., 2005. An Operational Definition Of Water Demand Management. Submitted To: International Journal Of Water Resources Development.

[7] Bushnak, A., 1997. Water Desalination And Wastewater Reuse: Review Of The Technology, Economics And Applications In The ESCWA Region. Expert Group Meeting On Development Of Non-Conventional Water Resources And Appropriate Technologies For Groundwater Management In The ESCWA Member Countries. 27-30 October, Manama, Bahrain. Economic And Social Commission Of Western Asia (ESCWA)/UN, Beirut.

[8] Dabbagh, A. E. And W. A. Abderrahman, 1997. Management Of Nroundwater Resources Under Various Irrigation Water Use Scenarios In Saudi Arabia. Arabian Journal Of Science And Engineering 22 (Special Theme Issue On Water Resources In The Arabian Peninsula), Pp. 47-64.

[9] Fao, 1997. Irrigation In The Near East Region In Figures. FAO Country Report Saudi Arabia 9 C. FAO Land And Water Division, Food And Agriculture Organization Of The United Nations, Rome 1997.

[10] Fao, 2009. Irrigation In The Middle East Region In Figures AQUASTAT Survey 2008. FAO Water Report 34, Country Report Saudi Arabia. Edited By Karen Frenken, FAO Land And Water Division, Food And Agriculture Organization Of The United Nations, Rome 2009, Pp. 325-337.

[11] Ishaq, A. M. And A. A. Khan, 1997. Recharge Of Aquifers With Reclaimed Wastewater: A Case For Saudi Arabia," Arabian Journal For Science And Engineering 22, Pp. 133-41 (Special Theme Issue On Water Resources In The Arabian Peninsula).

[12] Maw, 1984. (Ministry Of Agriculture And Water), Water Atlas Of Saudi Arabia, MAW, Riyadh.

[13] Maw, 1992. (Ministry Of Agric. And Water), Agricultural Statistical Year Book, Vol. 7, MAW, Department Of Economic Studies And Statistics, Riyadh. Kingdom Of Saudi Arabia.

[14] Mop, 1990. (Ministry Of Planning) Fifth Development Plan, MOP, Riyadh.

[15] K. H. Zaharani, M. Shayaa Al-Shayaa and M. B. Baig " Water Conservation in the Kingdom of saudi Arabia for better environment" Bulgarian Journal of Agricultural Science, 17 (No 3) 2011, 389-395.

[16] Siwi, 2009. Water Resources Of The Middle East. Background Report To Seminar On Water And Energy Linkages In The Middle East. Stockholm International Water Institute, (SIWI), Sweden.

[17] Unced, 2000. Executive Summary. The Third National Report For The Kingdom Of Saudi Arabia About The Implementation Of 
The United Nations Convention To Combat Desertification. UNCCD Program, Switzerland.

[18] U. S. Department Of Energy, 2002. Saudi Arabia: Environmental Issues. Energy Information Administration. Online Http://Www.Earthscape.Org/R1/ES15071/Doe_Saudi. Html.US Department Of Energy, 2002.

[19] Pmsaun, 2009. (Permanent Mission Of Saudi Arabia To United Nations). Development And The Environment In Saudi Arabia. Prepared By Permanent Mission Of Saudi Arabia To United Nations (PMSAUN). Http://Www.Un.Int/Saudiarabia/Ch146pln.Htm.

[20] Stylus studio, Open Geospatial Consortium, Inc, Whiteside. All Rights Reserved,2009.

[21] ESRI, Network Analysis, ESRI, Redlands, 1992.

[22] M. Birkin, G. Clarke, M. Clarke, A. Wilson, Intelligent GIS: Location Decisions and Strategic Planning, Geo Information, Cambridge, 1996.GIS and Petroleum Industry Anirban Acharya, Infotech Enterprises Ltd., Hyderabad, India.

[23] ArcGIS in the Oil and Gas Exploration Workflow - ESRI UC 2003. Kevin McLay, Roland Muggli, Safia Mazrui, PDO, Muscat, Oman.

[24] GIS Systems/Data Integration Success Guide Richard Salazar, Metropolitan Water District of Southern California, Los Angeles, USA.

[25] F. Al-Shamsam \& N. K. Puripanda, BAPCO The Use of GIS in Bahrain Oil Field Development \& Pipeline Management, Bahrain

[26] A Service Driven Approach for Integration of Heterogeneous Geospatial Data Repositories S.K. Ghosh, M. Paul, Indian Institute of Technology, Kharagpur, India.

[27] U .S.-Saudi Arabian Business Council. Public-Private Agreements Upgrade Saudi Water Infrastructure. U.S.-Saudi Business Brief. 9-10, 2010.

[28] T. Y. Al-Ghasham, et al., "Industrial Wastewater Treatment for Reuse, Assessment Study In A Saudi Aramco Facility," Saudi Aramco Journal of Technology, vol. Fall 2005, pp. 52-60, 2005.

[29] JETRO, "The Study on Wastewater Treatment and Water Reuse in Saudi Aramco, Saudi Arabia," Japan External Trade Organization (JETRO) Water Re-use Promotion Center, Sumitomo Corporation, Riyadh, January 2009.

[30] Aarcgis steamwater on March 6, 2009. http: ArcgisTeamWater@esri.com, Building and Maintaining Water Utility Geodatabases.

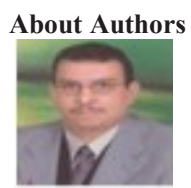

Magdy Shayboub: Was born in El- Menoufia, Egypt, in 1966. He received the B.Sc. degree in Electronic Engineering in 1989, and M.Sc. degree for his work in Computer Science and Engineering in 1998, all from the Faculty of Electronic Engineering, Menoufia University, Egypt. In 2005, he received his Ph. D. in Computer Science from Faculty of Computers and Informatics from Helwan University, Egypt. He is working as an assistant professor of computer science at the Faculty of Computers and Informatics, Suez Canal University, Egypt from 2006 until now. His research interests are in Artificial Intelligent (AI) Applications and Intelligent Agents (IA), Information Retrieval, Computer Networks Security and Semantic Web. Now is working a head of Medical Records Department and computer science in the Faculty of applied Medicine Science in Taif University, Kingdom of Saudi Arabia.

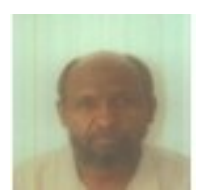

Samir M. Adam: Was born in Elfashir, on November 21, 1959.Graduated from U of G Faculty of Science and Technology in 1986 with a B.Sc.degree in Electronics, Instrumentation and applied physics .Graduated from U of K faculty of Mathematical Science Department of Computer with a M.Sc Degree in Computer Science 1996 .Ph.D in Computer Science University of Khartoum 2012. Computer programmer in NEC from 1986 until 1994Chief of Computer programmer section NEC from 1990-1994 .Omharaz NEC Computer Training Center manager 1994-1996.Computer teacher, Ministry of Education at Saudi Arabia from 1996 till 1999. Now is working an assistant professor of computer science at the Faculty of applied Medicine in Taif University, Kingdom of Saudi Arabia. 